\title{
White blood cell count of patients with oral squamous cell carcinoma at the time of diagnosis: a cross-sectional retrospective study of a population from southern Brazil
}

Kelem de Antoni Brunischaki ${ }^{\mathrm{a}}$, Myrian Camara Brew ${ }^{\mathrm{b}}$, Caren Serra Bavaresco ${ }^{\mathrm{b}}$,

Sergio Augusto Quevedo Miguens Jrb

\begin{abstract}
OBJECTIVE: To describe sociodemographic variables and verify changes in white blood cells of patients with oral squamous cell carcinoma

(OSCC).

METHODS: Cross-sectional retrospective study that used secondary data of patients with OSCC, attended at the Oral Medicine Service of the School of Dentistry of ULBRA, between 2010 and 2014. RESULTS: $87.3 \%$ of the population were male, white $(71 \%)$, age superior to 60 years $(38.7 \%)$, urban worker (61.3\%), without changing in the overall health at query time $(67.7 \%)$ and residents of the municipality of Canoas/RS (93.6\%). The most prevalent injuries sites were the buccal floor, alveolar ridge, corners of the mouth and gums (61.3\%). $74.2 \%$ of the sample were smokers and $45.2 \%$ drinkers. As for the WBC, most patients presented values within the normal range: total leukocytes (77.4\%), lymphocytes (87.1\%) and neutrophils (96.8\%).

CONCLUSION: The profile of the sample was consistent with literature: white males over the age of 40 years, smokers/former-smokers and alcoholics/ex-alcoholics. The patients did not show changes in the white blood cells (leukogram) values. It is recommended that more research should be conducted in this area of knowledge, due to the importance of the subject.
\end{abstract}

Keywords: carcinoma; squamous cell; mouth; white blood cells; inflammation.

\section{Contagem de glóbulos brancos de pacientes com carcinoma espinocelular bucal no momento diagnóstico: estudo transversal retrospectivo de uma população do sul do Brasil}

\section{RESUMO}

OBJETIVO: descrever o perfil sociodemográfico e verificar alterações nas células brancas do sangue de pacientes com Carcinoma Espino Celular Bucal (CECB).

MÉTODOS: estudo transversal retrospectivo que utilizou dados secundários de pacientes com CECB, atendidos no Serviço de Estomatologia do Curso de Odontologia da ULBRA, entre 2010 e 2014.

RESULTADOS: $87,3 \%$ da população eram de homens, brancos (71\%), com idade superior a 60 anos $(38,7 \%)$, trabalhadores urbanos $(61,3 \%)$, sem alteração de saúde geral no momento da consulta $(67,7 \%)$ e moradores do município de Canoas/RS (93,6\%). Os sítios mais prevalentes das lesões foram o assoalho bucal, rebordo alveolar, fundo de sulco, comissura labial e gengiva (61,3\%). $74,2 \%$ da amostra eram de fumantes e $45,2 \%$ eram etilistas. Quanto ao leucograma, a maioria dos pacientes apresentou valores dentro da normalidade de leucócitos totais $(77,4 \%)$, linfócitos $(87,1 \%)$ e neutrófilos $(96,8 \%)$.

CONCLUSÃO: o perfil da amostra foi compatível com o determinado na literatura: homens brancos com idade superior a 40 anos, fumantes/ex-fumantes e etilistas/ex-etilistas. Os pacientes não apresentaram alterações no leucograma, verificado pela contagem das células brancas do sangue. Recomenda-se que mais pesquisas sejam realizadas nesta área do conhecimento, devido à importância do tema.

Palavras-chave: carcinoma de células escamosas; boca; leucócitos; inflamação. a DDS, Sentinela do Sul, Rio Grande do Sul, Brazil b Professor, School of Dentistry, Lutheran University of Brazil - ULBRA, Canoas, Rio Grande do Sul, Brazil

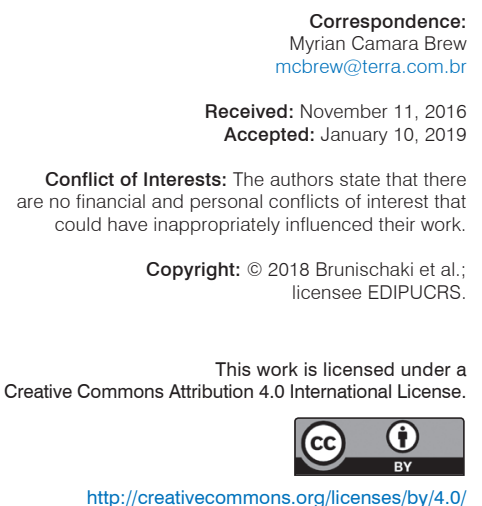

http://creativecommons.org/licenses/by/4.0/ 


\section{INTRODUCTION}

Oral squamous cell carcinoma (OSCC) is the most prevalent malignant neoplasm of the oral cavity (95\%), considered to be a heterogeneous disease due to its multifactorial etiology associated with intrinsic and extrinsic factors and its developmental mechanisms. The molecular mechanisms of its carcinogenesis, tumor progression and metastasis are related to multiple genetic alterations caused by chronic exposure to carcinogens such as smoking, alcohol, viral infections (HPV), dietary factors and inflammation $[1,2]$.

The development of an inflammatory state, or the maintenance of an existing inflammation, promotes cellular changes, causing suppression of immune responses, associated or not with the presence of bacterial or viral agents, and may act as a risk factor for the development of the lesion $[3,4]$. The role of chronic inflammation in carcinogenesis was first proposed by Rudolf Virchow in 1863, when he observed the presence of leukocytes in the neoplastic tissue $[5,6]$.

The possible mechanisms by which inflammation contributes to carcinogenesis are varied and included, the induction of genomic instability, favoring cell initiation, cellular resistance to apoptosis, tumor revascularization, changes in pro-inflammatory proteins, among others $[7,8]$.

If the inflammation is persistent, it will have the ability to induce cell proliferation and promote long cell survival, through the activation of oncogenes and inactivation of tumor suppressor genes. This will result in genetic instability with increased risk of injury. Tumor cells would induce the secretion of inflammatory mediators which, in turn, would promote the proliferation of tumor cells, the tumor progressing rapidly against an intense inflammatory infiltrate and/or its sub-products [4].

Studies with different methodologies have sought to establish the role of leukocyte cells present in the inflammatory infiltrate with the risk of developing cancer or even with the patient's prognosis before or after antineoplastic treatment. Among these, there are those who sought to know the changes in the hemogram or, more specifically, in the leukogram, to establish a relationship with the risk of tumor development $[9,10,11,12,13]$.

In their study of colon cancer risk, Lee et al. [10] observed that high white cell count in the leukogram was associated with a higher mortality risk in colon cancer patients, as well as a higher incidence of development of this tumor. The authors were able to conclude that chronic inflammation increased the risk for colon cancer.

Grivennikov, Greten, Karin [12] described the role of different inflammatory and immune cell types in antitumor immunity and inflammation promoted tumor, with neutrophils having a role in the inflammatory tumor promotion by the production of cytokines, proteases and oxygen reactive species; the $\mathrm{B}$ and $\mathrm{T}$ lymphocytes and their subtypes would act in the production of cytokines, immunosuppression, production of antibodies and activation of mast cells. The change in the number of these cells, specific or total, can be verified in the leukogram.

Despite the numerous studies that associate cancerinflammation, including those that seek to clarify the role of inflammation in head and neck cancer, few are directly related to tumors of the oral cavity, specifically to OSCC. Thus, the objective of this study was to verify leukogram, by counting white blood cells, at the time of diagnosis of OSCC, as well as to describe demographic, behavioral and clinical variables in order to investigate a possible relationship between this tumor and leukocytes values.

\section{METHODS}

A cross-sectional retrospective study of patients with clinical and histopathological diagnosis of OSCC attended at the Oral Medicine Service of the School of Dentistry of the Brazilian Lutheran University (ULBRA), city of Canoas/ RS, Brazil, from January 2010 to December 2014. Fortyone medical records were identified and 31 were selected from the eligibility criteria, which were: complete medical records presenting demographic, behavioral and clinical data, leukogram values at the time of the biopsy procedure for diagnosis, and histopathological confirmation for OSCC. Exclusion factor was: illegible medical records and/or the ones that were missing any inclusion criteria. This study is part of a research project approved by the Research Ethics Committee of ULBRA, number .572.901.

A spreadsheet was used to collect the data: demographic variables (age, gender, color and occupation), behavioral (smoking, alcohol), clinical information (comorbidities, type and location of the lesion) and leukogram values (white blood cells counting) at the time of OSCC diagnosis. The data collection was performed by a single investigator trained by an experienced researcher.

The study considered smokers who reported, at the time of the consultation, the use of one or more cigarettes per day. Those who quit the habit for at least 12 months prior to the consultation were considered to be formersmokers. The same parameters were used for alcohol consumption. These parameters were based on the study of Anaya-Saavedra et al. [14]. The values used as a parameter of leukogram analysis were those established by Failace [15].

The information collected was compiled into a database and analyzed in the statistical program SPSS version 22.0. The results were analyzed by descriptive analysis (absolute and relative frequency).

\section{RESULTS}

The study sample consisted mainly of males $(83.9 \%)$, older than $60(38.7 \%)$, white $(71 \%)$, who worked in the urban area $(61.3 \%)$ and resided in the municipality of Canoas (93.6\%). Most of the patients (67.7\%) had no comorbidities at the time of the diagnosis of OSCC (Table 1). 
Twenty-three patients $(74.2 \%)$ reported tobacco use and $14(45.2 \%)$ patients reported alcohol consumption. Of these, 13 patients used tobacco and alcohol concomitantly. However, seven patients (22.6\%) reported being formersmokers and nine (29\%) ex-alcoholics.

Table 1. Distribution of the demographic, behavioral and clinical variables of the patients with diagnosis of $C E C B$, of the Oral Medicine Service of the School of Dentistry - ULBRA, Canoas/RS, Brazil, $(n=31)$

\begin{tabular}{|c|c|c|}
\hline Variables & $\mathrm{N}$ & $\%$ \\
\hline \multicolumn{3}{|l|}{ Gender } \\
\hline Male & 26 & 83.9 \\
\hline Female & 05 & 16.1 \\
\hline \multicolumn{3}{|l|}{ Age (years) } \\
\hline$\leq 39$ & 02 & 6.5 \\
\hline $40-50$ & 06 & 19.3 \\
\hline $50-60$ & 11 & 35.5 \\
\hline$>60$ & 12 & 38.7 \\
\hline \multicolumn{3}{|l|}{ Color } \\
\hline Withe & 22 & 71 \\
\hline Black & 05 & 16.1 \\
\hline $\mathrm{NI}$ & 04 & 12.9 \\
\hline \multicolumn{3}{|l|}{ Ocupation } \\
\hline Urban worker & 19 & 61.3 \\
\hline Rural worker & 01 & 3.2 \\
\hline Other (retire, unemployed) & 10 & 32.3 \\
\hline $\mathrm{NI}$ & 01 & 3.2 \\
\hline \multicolumn{3}{|l|}{ Comorbidities } \\
\hline Yes & 10 & 32.3 \\
\hline No & 21 & 67.7 \\
\hline \multicolumn{3}{|l|}{ Tabacco } \\
\hline Yes & 23 & 74.2 \\
\hline No & 01 & 3.2 \\
\hline Former smokers & 07 & 22.6 \\
\hline \multicolumn{3}{|l|}{ Alcohol } \\
\hline Yes & 14 & 45.2 \\
\hline No & 08 & 25.8 \\
\hline Ex-alcoholics & 09 & 29 \\
\hline
\end{tabular}

Regarding the location of OSCC, there was variability in the sample. Nineteen cases $(61.3 \%)$ occurred in the regions of the buccal floor, gingival border, sulcus and labial commissure. The others were located in the tongue $(9.7 \%)$, the lip $(12.9 \%)$, the oropharynx/retromolar region $(12.9 \%)$ and the palate $(3.2 \%)$.

In the total leukocyte count, leukocytosis was observed in seven cases $(22.6 \%)$ (Table 2), and the mean $(\mathrm{dp})$ in the sample was $8,635( \pm 1,795)$ leukocytes. Thus, the mean values of the sample were within the normal range.

Regarding the individual analysis of the white-cells series, one case $(3.2 \%)$ presented lymphocytosis and three $(9.7 \%)$ lymphopenia. The mean (dp) of patients' lymphocytes was $2,285( \pm 641)$ cells and, in one case $(3.2 \%)$, neutrocytosis were observed (Table 2).
Table 2. Distribution of total leukocytes, lymphocytes and neutrophils at the time of diagnosis of patients with SOCC, of the Oral Medicine Service of the School of Dentistry - ULBRA, Canoas/RS, Brazil, $(n=31)$.

\begin{tabular}{lcc}
\hline Cells values (leukogram) & N & $\%$ \\
Leukocytes & & \\
Normal $\left(4.000-10.000 / \mathrm{mm}^{3}\right)^{*}$ & 24 & 77.4 \\
Leucocitose & 07 & 22.6 \\
Lymphocytes & & \\
Normal $\left(1.500-3.500 / \mathrm{mm}^{3}\right)^{*}$ & 27 & 87.1 \\
Lymphocytosis & 01 & 3.2 \\
Lymphopenia & 03 & 9,7 \\
Neutrophils & & \\
Normal $\left(1.600-8.000 / \mathrm{mm}^{3}\right)^{*}$ & 30 & 96.8 \\
Neutrocytosis & 01 & 3.2 \\
\hline
\end{tabular}

* Reference values according Failace [15].

\section{DISCUSSION}

Epidemiological studies allow the identification of a risk profile for the development of OSCC. White men over the age of 40 are at risk and are continuously exposed to risk factors associated with the tumor $[16,17,18]$.

The main etiological factors documented in the literature for OSCC are represented by the use of tobacco, alcohol and the combination of both [16]. It is also observed that the risk for developing OSCC increases with the inclusion of smoking among nonsmokers and that the risk is 35 times higher in those who smoke (more than 2 packs per day) and consume alcohol (more than 4 doses per day) [19]. The results of the study are in agreement with the literature, since the majority of patients were smokers and / or alcoholics.

Studies have shown that OSCC has preferential localization of the lower lip (38\%), the tongue (22\%) and the floor of the mouth (17\%). The remaining 23\% are distributed in the gums, palate, tonsils, upper lip, jugal mucosa and uvula $[18,20]$. The results of the present research, both for the patient profile and for the lesion distributions, are in agreement with the literature $[17,19,20,21]$.

It has been observed that the inflammatory state, its development or its maintenance, can promote cellular alterations, causing suppression of the immune responses and favoring the development of the cancer. The presence of chronic inflammation, caused by persistent chemicals, bacteria or viruses (HPV), is a risk factor for cancer. However, inflammation alone is rarely capable of inducing malignant neoplasm. Regarding buccal mucosa tumors, there are several inflammatory changes affecting the mucosa, but the incidence of cancer in this tissue is relatively uncommon $[4,7,22,23]$.

The sample of this study did not present alteration in the standard of normality of the leukogram at the time of OSCC patients' diagnosis, and, therefore, did not confirm the hypothesis of an association between the presence of the malignant neoplasm and alterations in the white cells values (leucogram). However, a sample with a greater 
number of cases, as well as the inclusion of pre-malignant lesions, as already reported in other studies, is necessary to confirm a possible association between these variables $[9,10,11,12,13,24]$.

However, when total leukocyte abnormalities were observed in the patients in this study, it was not exclusively related to changes in the number of neutrophils and/or lymphocytes, showing alterations in the other cells in the white blood series. Only one case presented alteration in the total leukocytes that was related to the alteration of lymphocytes (leukocytes $=10,890 / \mathrm{mm}^{3}$ and lymphocytes $=4.073 / \mathrm{mm}^{3}$ ). However, in both values, the change was discrete, using the reference values of the research [15]. In another patient, the leukocyte change was related to the increase in neutrophils (leukocytes $=11,300 / \mathrm{mm}^{3}$ and neutrophils $=8,362 / \mathrm{mm}^{3}$ ).

Many studies have been carried out seeking to establish a relationship with the elevation of white blood cells with a higher risk of mortality in patients with colon cancer, as well as with a higher incidence of the development of this neoplasm. These studies were able to conclude that chronic inflammation increased the risk for cancer, in addition to be a marker widely available for inflammation [10.25].

As far as oral cavity lesions are concerned, few studies associate cancer with inflammation. In the study by Tsai et al. [13], the authors associated a high monocyte count pretreatment of OSCC with an unfavorable prognosis. They also observed that increased monocyte, neutrophil, and neutrophil/ lymphocyte rates were associated with the advancement of tumor clinical staging, although the isolated rate of lymphocytes decreased. The study by Lundqvist et al. [26] in OSCC of the $\mathrm{t}$, observed the relationship between inflammatory infiltrate and the choice of treatment to be performed.

\section{CONCLUSION}

The majority of the patients were male, white and older than 60 years, residents of the municipality of Canoas, with urban labor activity, being smokers/former-smokers and alcohol/ex-alcoholics. The leukogram values (white blood cells counting) did not show alterations related to the diagnosis of OSCC in the patients of the studied sample.

Researches that seek to know the association of changes in leukogram with cancer have demonstrated the need for the development of longitudinal observational studies with inclusion and analysis of hemograms before, during and after the beginning of cancer treatment so that the use of this examination can be an important instrument for prognostic control and/or prediction. Few studies associate cancer with inflammation. With regard to OSCC, these studies would be even more important due to the small number of studies found in the literature.

\section{REFERENCES}

1. Feller I, Lemmer J. Oral squamous cell carcimona: epidemiology, clinical presentation and treatment. J Can The 2012;3(4):263-8

2. Sasahira T, Kirita T, Kuniyasu $H$. Update of molecular pathobiology in oral cancer: a review. Int J Clin Oncol. 2014;19(3):431-6. https://doi. org/10.1007/s10147-014-0684-4
3. O'Byrne KJ, Dalgleish AG. Chronic immune activation and inflammation on the cause of malignancy. British Journal of Cancer 2001;85(4):473-3. https://doi.org/10.1054/bjoc.2001.1943

4. Feller L, Altini M, Lemmer J. Inflammation in the context of oral cancer. Oral Oncol 2013 Sept;49(9):887-92. https://doi.org/10.1016/j. oraloncology.2013.07.003

5. Balkwill F, Mantovani A. Inflammation and cancer: back to Virchow? Lancet 2001 Feb 17;357(9255):539-45. https://doi.org/10.1016/S01406736(00)04046-0

6. Coussens LM, Werb Z. Inflammation and cancer. Nature 2002 Dec 19-26;420(6917):860-7. https://doi.org/10.1038/nature01322

7. Hussain SP, Harris CC. Inflammation and cancer: an ancient link with novel potentials. Int J Cancer 2007 Dec 1;121(11):2373-80. https://doi. org/10.1002/ijc.23173

8. Kundu JK, Surh YJ. Inflammation: gearing the journey to cancer. Mutat Res 2008 Jul-Aug;659(1-2):15-30. https://doi.org/10.1016/j.mrrev.2008.03.002

9. Aggarwal BB, Gehlot P. Inflammation and cancer: how friendly is the relationship for cancer patients? Curr Opin Pharmacol. 2009 Aug;9(4): 351-69. https://doi.org/10.1016/j.coph.2009.06.020

10. Lee YJ, Lee HR, Nam CM, Hwang UK, Jee SH. White blood cell count and the risk of colon cancer. Yonsei Med J. 2006 Oct 31;47(5):646-56. https:// doi.org/10.3349/ymj.2006.47.5.646

11. Qiu MZ, Xu RH, Ruan DY, Li ZH, Luo HY, Teng KY, Wang ZQ, Li YH, Jiang WQ. Incidence of anemia, leukocytosis, and thrombocytosis in patients with solid tumors in China. Tumour Biol. 2010 Dec;31(6):633-41. https:// doi.org/10.1007/s13277-010-0079-8

12. Grivennikov SI, Greten FR, Karin M. Immunity, inflammation, and cancer. Cell. 2010 Mar 19;140(6):883-99. https://doi.org/10.1016/j. cell.2010.01.025

13. Tsai YD, Wang CP, Chen CY, Lin LW, Hwang TZ, Lu LF, Hsu HF, Chung FM, Lee YJ, Houng JY. Pretreatment circulating monocyte count associated with poor prognosis in patients with oral cavity cancer. Head Neck. 2014 July;36(7):947-53. https://doi.org/10.1002/hed.23400

14. Anaya-Saavedra G, Ramírez-Amador V, Irigoyen-Camacho ME, GarcíaCuellar CM, Guido-Jiménez M, Méndez-Martínez R, García-Carrancá A. High association of human papillomavirus infection with oral cancer: a case-control study. Arch Med Res. 2008 Feb;39(2):189-97. https://doi. org/10.1016/j.arcmed.2007.08.003

15. Failace R. Hemograma. Manual de interpretação. 5a ed. Porto Alegre, editora Artmed, 2009. p.424.

16. Massano J, Regateiro FS, Januário G. Ferreira A. Oral squamous cell carcinoma: review of prognostic and predictive factors. Oral Surg Oral Med Oral Pathol Oral Radiol Endod 2006 July; 102(1):67-76. https://doi. org/10.1016/j.tripleo.2005.07.038

17. Chaturvedi AK, Engels EA, Anderson WF, Gillison ML. Incidence trends for human papillomavirus-related and -unrelated oral squamous cell carcinomas in the United States. J Clin Oncol 2008 Feb 1;26(4):612-9. https://doi.org/10.1200/JCO.2007.14.1713

18. Werner EJ; Fontanella V. Perfil epidemiológico dos pacientes portadores de câncer bucal atendidos no Hospital Santa Rita, Porto Alegre/RS. Stomatos 2009;15(28):3-16.

19. Blot WJ, McLaughlin JK, Winn DM, Austin DF, Greenberg RS, PrestonMartin $S$ et al. Smoking and drinking in relation to oral and pharyngeal cancer. Cancer Res 1988 June;48(11):3282-7.

20. De Petrini M, Rittà M, Schena M, Chiusa L, Campisi P, Giordano C et al. Head and neck squamous cell carcinoma: role of the human papillomavirus in tumour progression. New Microbiol 2006 Jan;29(1):25-33.

21. Merletti F, Boffetta P, Ciccone G, Mashberg A, Terracini B. Role of tobacco and alcoholic beverages in the etiology of cancer of the oral cavity/ oropharynx in Torino, Italy. Cancer Res 1989 Sept 1;49(17):4919-24.

22. Erlinger TP, Muntner P, Helzlsouer KJ. WBC count and the risk of cancer mortality in a national sample of U.S. adults: results from the Second National Health and Nutrition Examination Survey mortality study. Cancer Epidemiol Biomarkers Prev. 2004 June;13(6):1052-6.

23. Mantovani A. Molecular pathways linking inflammation and cancer Curr Mol Med. 2010 June;10(4):369-73. https://doi.org/10.2174/156652 410791316968

24. Guo YH etal. The clinical use of the platelet/lymphocyte ratio and lymphocyte/monocyte ratio as prognostic predictors in colorectal cancer: a meta-analysis. Oncotarget 2017 Mar 21;8(12):20011-24.

25. Shankar A, Wang JJ, Rochtchina E, Mitchell P. Association between selfrated health and incident severe hypertension among men: a populationbased cohort study. Singapore Med J. 2008 Nov;49(11):860-7.

26. Lundqvist L, Stenlund H, Laurell G, Nylander K. The importance of stromal inflammation in squamous cell carcinoma of the tongue. J Oral Pathol Med. 2012 May;41(5):379-83. https://doi.org/10.1111/j.1600-0714.2011.01107.x 